\title{
Unusual case of bilateral ciliary madarosis: trichotillomania
}

\author{
Sahil Agrawal 조 , Mohd Sabir, Sujeeth Modaboyina 주, Deepsekhar Das
}

Ophthalmology, Dr Rajendra Prasad Centre for Ophthalmic Sciences, AllMS, New Delhi, Delhi, India

\section{Correspondence to} Dr Deepsekhar Das; doc.deep.das@gmail.com

SA and SM contributed equally.

Accepted 15 October 2021

Check for updates

(c) BMJ Publishing Group Limited 2021. No commercial re-use. See rights and permissions. Published by BMJ.

To cite: Agrawal S, Sabir M, Modaboyina $\mathrm{S}$, et al. BMJ Case Rep 2021;14:e244215. doi:10.1136/bcr-2021-

244215

\section{DESCRIPTION}

Trichotillomania is an impulse-control psychiatric disorder characterised by compulsive plucking and removal of body hair. The commonly involved sites are scalp, eyebrows, eyelashes and pubic hair. Here, we present this unusual case of bilateral ciliary madarosis.

An 18-year-old female patient presented to an ophthalmology Out Patient Department (OPD) with complaints of loss of eyelashes for the past 3 weeks. On further enquiry, her parents informed her that patient herself plucks the eyelashes whenever they grow. The patient complained of intense itching, for which she removed the eyelashes and trimmed some with a pair of scissors, followed by relief of symptoms. There was no history of any dermatological disorder or psychiatric disorder in the past or in the family. There was no history of any systemic medication.

On general examination, the patient was alert, conscious and co-operative with stable vitals. There were no obvious signs of hyperthyroidism, malnutrition or any dermatological disorder.

On ophthalmological examination, the eyelids appeared thickened with patches of absent lashes along with patches of broken short cilia at different levels. Several signs such as black dots indicating broken hair, $\mathrm{V}$ sign corresponding to two broken hairs arising from one pilar orifice and tulip sign showing tulip flower shaped hairs were suggestive of trichotillomania (figure 1). The hair pull test was negative, which would otherwise be present in alopecia areata (AA). Visual acuity was $6 / 6$ in either eye. The conjunctiva, anterior segment and posterior segments were within normal limits on slit-lamp examination. Blood investigation revealed a normal haemogram, erythrocyte sedimentation rate, serum electrolytes and thyroid profile.

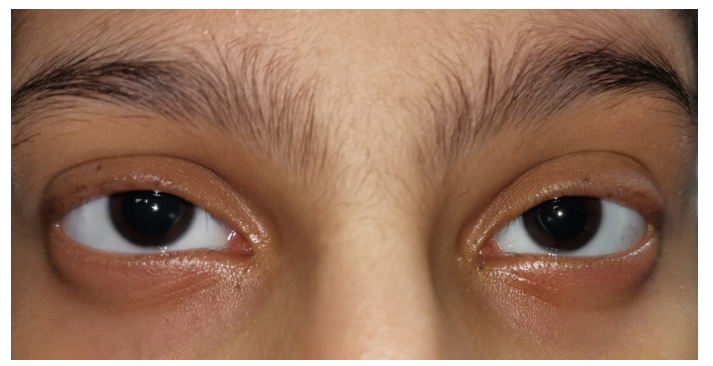

Figure 1 Clinical picture of the patient showing bilateral patchy absence of hair and patches of small broken cilia.
Based on clinical history of voluntary pulling and clinical signs, a diagnosis of trichotillomania was made. The patient was sent to the psychiatry department for commencing psychotherapy and behaviour modification training.

Ciliary madarosis or milphosis is a form of alopecia wherein there is loss of eyelashes. ${ }^{1}$ The common causes of ciliary madarosis include blepharitis, seborrheic dermatitis, atopic dermatitis, xeroderma pigmentosa, hyperthyroidism and AA. $^{2-5}$

Among blepharitis, anterior blepharitis is associated with milphosis most commonly. It is characterised by symptoms of itching, burning, foreign body sensation and photophobia. On slit-lamp examination, scruff, collarettes and sleeves are seen along the lash margins. ${ }^{2}$ Although our patient had a history of itching and foreign body sensation, there were no clinical signs; thus, blepharitis was ruled out. AA is another common differential that should be considered in cases of itching associated with loss of eyelashes. In AA exclamation mark is seen and occasionally white hair can also be noted. Even though trichotillomania is commonly seen in upper eyelid as compared with both eyelids in AA, in present case, both eyelids showed loss of eyelashes. In cases where even clinically AA cannot be differentiated from trichotillomania, a biopsy is indicated. ${ }^{6}$ Trichotemnomania is a psychiatric disorder where the affected individual has a tendency or shaving and trimming of hair. ${ }^{1}$ Our patient had both trichotillomania and trichotemnomania. However, the absence of clinical signs hinted more towards a psychiatric disorder.

Trichotillomania in children usually has a benign course which is precipitated by stressors such as sibling rivalry, lack of parental affection and nocturnal enuresis. ${ }^{7}$ Trichotillomania in preadolescents to young adults, which is the common age of presentation, tend to have chronic and relapsing courses. N-acetyl cysteine, tricyclic antidepressants and selective serotonin uptake inhibitors have shown good response. ${ }^{8}$ If trichotillomania is associated with pre-existing depression or bipolar disorders, it should be managed accordingly. The mainline of management of trichotillomania involves behaviour modification therapies primarily given by psychologists and in certain scenarios, topical bimatoprost application has been attempted. ${ }^{19}$ To the best of our knowledge,$^{10}$ this is the first such case of bilateral ciliary madarosis to be reported post trichotillomania. 


\section{Patient's perspective}

I am grateful that my doctors could identify the underlying cause and provide me a timely help for possible recovery.

\section{Learning points}

- Early diagnosis of underlying trichotillomania helps in early and fruitful management.

- It requires multidisciplinary approach by ophthalmologist, psychiatrist and psychologist, for a comprehensive outcome.

Contributors DD and SA were the primary point of contact of the patient and the operating surgeons. They also helped in critical revision of the article. MS helped in collecting data and clinical images of the patient and review of the literature. SM drafted the article.

Funding The authors have not declared a specific grant for this research from any funding agency in the public, commercial or not-for-profit sectors.

Competing interests None declared.

Patient consent for publication Consent obtained directly from patient(s).
Provenance and peer review Not commissioned; externally peer reviewed.

\section{ORCID iDs}

Sahil Agrawal http://orcid.org/0000-0001-6667-249X

Sujeeth Modaboyina http://orcid.org/0000-0002-1306-5722

Deepsekhar Das http://orcid.org/0000-0002-4446-0274

\section{REFERENCES}

1 Kumar A, Karthikeyan K. Madarosis: a marker of many maladies. Int J Trichology 2012;4:3-18.

2 Khong JJ, Casson RJ, Huilgol SC, et al. Madarosis. Surv Ophthalmol 2006;51:550-60.

3 Pandhi D, Singal A, Rohtagi J. Eyelid involvement in disseminated chronic cutaneous lupus erythematosus. Indian J Dermatol Venereol Leprol 2006:72:370-2.

4 Gupta AK, Madzia SE, Batra R. Etiology and management of seborrheic dermatitis. Dermatology 2004;208:89-93.

5 MacDonald Hull SP, Wood ML, Hutchinson PE. British association of dermatologists. guidelines for the management of alopecia areata. Br J Dermatol 2003;149:692-9.

6 King RA, Scahill L, Vitulano LA, et al. Childhood trichotillomania: clinical phenomenology, comorbidity, and family genetics. J Am Acad Child Adolesc Psychiatry 1995:34:1451-9.

7 Sah DE, Koo J, Price VH. Trichotillomania. Dermatol Ther 2008;21:13-21.

8 Barroso LAL, Sternberg F, Souza MNIdeFE, et al. Trichotillomania: a good response to treatment with N-acetylcysteine. An Bras Dermatol 2017;92:537-9.

9 Peabody T, Reitz S, Smith J, et al. Clinical management of trichotillomania with bimatoprost. Optom Vis Sci 2013;90:e167-71.

10 Sachdeva S, Prasher P. Madarosis: a dermatological marker. Indian J Dermatol Venereol Leprol 2008;74:74-6.

Copyright 2021 BMJ Publishing Group. All rights reserved. For permission to reuse any of this content visit

https://www.bmj.com/company/products-services/rights-and-licensing/permissions/

BMJ Case Report Fellows may re-use this article for personal use and teaching without any further permission.

Become a Fellow of BMJ Case Reports today and you can:

- Submit as many cases as you like

- Enjoy fast sympathetic peer review and rapid publication of accepted articles

- Access all the published articles

- Re-use any of the published material for personal use and teaching without further permission

\section{Customer Service}

If you have any further queries about your subscription, please contact our customer services team on +44 (0) 2071111105 or via email at support@bmj.com.

Visit casereports.bmj.com for more articles like this and to become a Fellow 